\title{
Syyllisyyden kirjoittuminen rikoksesta epäillyn kuulustelukertomukseen
}

\author{
Jutta Helenius
}

\begin{abstract}
How guilt or innocence is constructed in Finnish suspects written police records
\end{abstract}

The present study focuses on written police records in Finland. The aim is to investigate how guilt or innocence is constructed in written police records. The research data contains 168 copy of suspects police records from Helsinki, Tampere and Turku police departments. Police records are being analyzed by using the discursive and linguistic approach. The results show that there are nine discursive categories in which guilt is constructed. The results also show that there are three types of metafunctions in which guilt is constructed: content, interaction and linguistic presentation. All them together construct the guilt in suspects police records.

Keywords: guilt, police interviews, police records

\section{JOHDANTO}

Poliisi kirjaa kuulusteltavan puhuman kertomuksen kuulustelutilanteen institutionaalisessa vuorovaikutuksessa kuulustelupöytäkirjaan. Se, millaiseksi tekstiksi kertomus kirjataan, vaikuttaa kuulustellun henkilön elämään ja oikeusturvaan (Käsikirja esitutkintapöytäkirjan laadinnasta 2007, 1). Rikoksesta epäillyn oikeusturvan takeena on syyttömyysolettama: "jokaista rikoksesta epäiltyä ja syytettyä on pidettävä syyttömänä, kunnes hänen syyllisyytensä on laillisesti näytetty toteen" (Korkein oikeus 2014).

Kuulustelukertomuksella selvitetään, täyttäisikö rikosepäily rikoksen edellytykset (rikosepäilystä Pölönen 2003, 252-253), joita ovat tunnusmerkistön mukaisuus, oikeudenvastaisuus ja syyllisyys (Frände 2005, 10-11; Nuutila 2016). Tekstillä selvitetään, "onko riittävää aihetta syytteen nostamiseen epäillystä rikoksesta" (Käsikirja esitutkintapöytäkirjan laadinnasta 2007, 1), dokumentoidaan rikoksen tutkintaa (Ellonen, Karstinen \& Nykänen 1996, 7) sekä tarjotaan syyttäjäviranomaiselle syyteharkinnan mahdollistava dokumentti.

Kuulustelukertomus on hyvin yleinen teksti. Poliisille ilmoitettiin Suomessa 809368 rikosta vuonna 2016 (Poliisin tulostietojärjestelmä PolStat 2017). Kaikki rikokset eivät kuitenkaan etene esitutkintaan tai kuulusteluihin, eikä kaikkia osallisia aina kuulustella. Kuulustelukertomusten määräksi voidaan kuitenkin rikosten määrän perusteella arvioida kymmeniä tuhansia vuodessa.

Kuulustelukertomus on yhteiskunnallisesti merkittävä ja yleinen viranomaisteksti, joka liittyy esitutkintaan ja syyteharkintaan. Hallintoviranomaisina poliisi ja oikeuslaitos tuottavat ja käyttävät juridis-hallinnollisen päätöksenteon tekstejä. Artikkeli tarjoaa analyysillään uutta tietoa siitä, miten esitutkinta ja syyteharkinnan pohjustus tapahtuvat kielellisesti, sillä kuulustelukertomuksia ei ole Suomessa tutkittu teksti(laji)n ja kielen näkökulmasta. Aiemmat tutkimukset ovat etupäässä juridisista näkökulmista (mm. Karstinen 1998, 10). Kuulustelukertomuksia ei myöskään ole tarkasteltu institutionaalisina teksteinä, toisin kuin sosiaali- ja terveysalan tekstejä. Niitä on tutkittu eritoten kielentutkimuksessa (esim. Elämän ja kuoleman tekstit -kokoelma 2017). Artikkeli tuo lisäksi hallinnon tutkimuksen kannalta yhden näkökulman siihen pohdintaan, millaisia tekstejä voidaan pitää päätöksenteossa toimivina. Artikkelin analyysin voi myös väljästi liittää hallintoviranomaisten toiminnan ja työkäytänteiden tarkasteluun. 
Tarkastelen artikkelissa seuraavia tutkimuskysymyksiä:

1. Millaisten diskursiivisten käytänteiden eli vuorovaikutuksellisen toiminnan tapojen (mm. Pietikäinen \& Mäntynen 2009, 35) avulla syyllisyys tai syyttömyys kirjoittuu rikoksesta epäillyn kuulustelukertomukseen?

2. Millaisin kielellisin valinnoin syyllisyys tai syyttömyys kirjoittuu rikoksesta epäillyn kuulustelukertomukseen?

Tutkimuskysymyksillä on tiivis ja kaksisuuntainen yhteys. Diskursiiviset käytänteet rakentuvat kielellisten valintojen avulla. Toisaalta käytänteet vaikuttavat siihen, millaisia kielellisiä valintoja kuulustelukertomuksessa tehdään. Tutkimuskysymysten taustalla on poliisin tehtävistä kaksi eli rikosten selvittäminen ja syyteharkintaan saattaminen (poliisilaki 493/1995, 1. \$ ja poliisilaki 872/2011, 1. \$), mitkä toteutuvat käytännössä esitutkinnassa. Poliisi ei ota kantaa syyllisyyteen, mutta hän voi tiedustella kuulusteltavan kantaa syyllisyyteen (Käsikirja esitutkintapöytäkirjan laadinnasta 2007, 19; Helenius 2014, 31). Rikoksesta epäillyn kuulustelua on merkityksellistä tutkia myös siksi, että epäillyn kuulustelu on usein keskeinen, jopa ratkaiseva näyttö rikosjutuissa (Pölönen 2003, 250).

Hyödynnän artikkelissa kielitieteellisiä lähteitä sekä osin hallintotieteellisiä lähteitä. Lisäksi tukeudun oikeuskirjallisuuteen.

\section{SYYTÖKSEEN JA SYYLLISYYTEEN LIITTYVÄ PRESUPPOSITIO SEKÄ REPRESENTAATIO}

Kuulustelukertomuksen tarkastelussa oleellinen käsite on presuppositio, olettamus, joka on edellytyksenä jonkin lauseen esittämälle väitteelle (mm. Pietikäinen \& Mäntynen 2009, 126; van der Sant 2010, 36-37). Presuppositiona on syytös jostakin rikoksesta, ja hallinnollisesti kuulustelukertomus on syytökseen ja syyllisyyden selvittämiseen liittyvä konstruktio. Johnson $(2007,98)$ pitää [kuulustelu]kertomuksia kaikkia koskettavina kertomuksina syyllisyydestä ja syyttömyydestä.

Kuulustelukertomuksia voidaan tarkastella representaationkin käsitteen avulla. Kuulustelukertomuksen kirjaava viranomainen representoi eli esittää ja merkityksellistää tapahtumia, jotka liittyvät rikosepäilyyn, syytökseen ja syyllisyyskysymykseen. Representointi tapahtuu aina jos- takin näkökulmasta. (Pietikäinen \& Mäntynen 2009, 53, 56; Vainikkala 2012, 566.) Kyse on kuulustelutilanteessa tietyllä tavalla rakennetusta, rikosepäilyyn liittyvän todellisuuden kuvasta, ei todellisuudesta sellaisenaan (ks. Pölönen 2003, 340; 342). Representaatio on yhteydessä määrittelyvaltaan ja erilaisiin käytäntöihin liittyvään merkityskamppailuun (Vainikkala 2012, 566). Representaatioilla katsotaan olevan tuottavaa voimaa (emt.), ja rikosepäilyn representointitavalla on kansalaiselle erilaisia seurauksia.

\section{KUULUSTELUKERTOMUKSEEN LIITTYVÄSTÄ SÄÄNTELYSTÄ JA KUULUSTELUKERTOMUKSEN KIRJAAMISESTA}

Kuulustelutilannetta ja kuulustelukertomuksen kirjaamista säännellään eri tavoin, ja käsittelen sääntelyä seuraavaksi. Tutkimusaineistoni kuulustelut ovat vuosilta 2007-2008. Tuolloin kuulustelun toimittamista ja kirjaamista ovat säännelleet esitutkintalaki (1987, 22.-39. §:t) sekä asetus esitutkinnasta ja pakkokeinoista (1988, 12.-18. §:t). Lisäksi kuulustelukertomuksen kirjaamista on ohjeistettu teoksessa "Käsikirja esitutkintapöytäkirjan laadinnasta" (2007, uudempi 2010). Uusi esitutkintalaki (22.7.2011/805) on astunut voimaan 1.1.2014.

Erityisesti ns. itsekriminointisuojaa on vahvistettu esitutkintalain uudistuksessa. Itsekriminointisuojalla tarkoitetaan sitä, että epäillyn ei tarvitse kertoa kuulustelussa tietoja, joiden vuoksi hänet voidaan tuomita. Artikkelissa hyödynnetyt esitutkinta- ja pakkokeinolait sekä esitutkintapöytäkirjan kirjaamisohjeet ovat kuvattavissa Solinin $(2012,350)$ luonnehdinnan mukaan keskusjohtoisesti luoduiksi säätelyteksteiksi, jotka liittyvät institutionaalisiin tekstilajien säätelyprosesseihin. Säätelyprosessit kertovat instituutioiden erityislaatuiseen kirjoittamiseen liittyvistä arvostuksista sekä siitä, millaisten tekstien nähdään olevan toimivia päätöksenteon kannalta (emt).

Poliisi valitsee strategian (Hahn \& Schicht 1992), jota noudattamalla hän saa kirjatuksi lakien ja ohjeiden mukaisen kuulustelukertomuksen. Käsikirjassa esitutkintapöytäkirjan laadinnasta $(2007,14)$ ohjeistetaan kirjaamaan kuulustelukertomus "niin tarkasti kuin sillä voidaan olettaa olevan merkitystä asiassa" ja kiinnittä- 
mään huomiota erityisesti rikoksen tunnusmerkistöön, jonka "tapahtumakulku mahdollisesti toteuttaa". Tämän voitaneen jo ajatella ohjaavan kirjaamaan kuulustelukertomukseen syyllisyyttä tukevaa aineistoa. Strategia vaikuttaa kuulustelumenetelmän valintaan, kuulustelutilanteen etenemiseen sekä kertomuksen muotoutumiseen (Karstinen 1998, 111; Pölönen 2003, 342; Helenius 2016, 228).

Kuulustelu voidaan kirjata vapaalla kerronnalla, kysymys-vastaus-menetelmällä tai edellisten yhdistelmällä. Kuulustelukertomuksen alkuun kirjataan yleensä esitutkintalain (1987) 29.-30. \$:ien mukaisesti kuulusteltavan asema, oikeudet ja velvollisuudet (esimerkki 1):

Minulle on kerrottu asemani sekä oikeuteni ja velvollisuuteni tässä kuulustelussa (Helsinki, kuulustelukertomus 32, s. 2).

Kertomuksen lomaan voi sisältyä lihavoituja kysymyksiä tai kuulustelijan merkintöjä, jotka kuvaavat olosuhteiden muutosta kuulustelun aikana, tunnistamista ja rekonstruktiotoimenpiteitä, todisteiden esittämistä tai kuulustelun keskeytystä (Käsikirja esitutkintapöytäkirjan laadinnasta 2007, 22; Vesterbacka 2007, 31).

Kuulustelupöytäkirja-lomakkeeseen kirjataan kuulusteltavan henkilötietojen jälkeen hänen kuulustelukertomuksensa. Kirjauksen jälkeen kuulusteltava tarkastaa ja hyväksyy tekstin tai pyytää kuulustelijaa tekemään tekstiin korjauksia tai lisäyksiä. Muutosten jälkeen kuulusteltava, kuulustelija ja mahdollinen kuulustelutodistaja allekirjoittavat lomakkeen. Kuulusteltava voi myös kieltäytyä allekirjoittamasta lomaketta. Oikeusturvan näkökulmasta teksti ja kuulusteltavan sen allekirjoituksellaan osoittama hyväksyntä on merkittävä. Pölösen $(2003,340)$ mukaan hyväksyntä ei kuitenkaan ole ongelmaton, sillä kuulustelukertomus ei ole sanatarkka kopio kuulustelusta. Kuulustelukertomus on poliisin tulkinta siitä, mitä ja miten kuulustelussa on sanottu (ks. Pölönen 2003, 340). Teksti on siinäkin suhteessa representaatiota.

\section{AINEISTO JA MENETELMÄT}

Artikkelin tekstiaineistona on 168 omaisuusrikoksista epäillyn julkista kuulustelukertomusta Helsingistä, Tampereelta ja Turusta. Toimisto- henkilöt ovat valinneet kuulustelukertomukset kaupunkien poliisilaitoksen arkistosta antamieni kriteerien perusteella. Valintakriteerinä on ollut rikostyyppi eli ns. massarikokset (tarkemmin jäljempänä) sekä kuulusteltavan asema, rikoksesta epäilty. Tekstiaineisto on rajattu vuosille 2007-2008, jotta saataisiin ajallista etäisyyttä tutkimushetkeen ja vähennettäisiin rikostapausten mahdollista tunnistettavuutta. Lisäksi aineisto on pyritty keräämään suurehkojen kaupunkien keruuajan poliisipiireistä. Tekstiaineisto kattaa luonnollisesti vain osan rikostapauksista. Aineisto on autenttista, mutta ei täysin kontrolloimaani, koska konkreettisen poiminnan ovat tehneet Helsingin, Tampereen ja Turun poliisilaitosten toimistohenkilöt. Olen valinnut artikkelissa analysoitavat kuulustelukertomukset sillä perusteella, että ne edustavat aineistolle ominaisia piirteitä ja sopivat pituudeltaan tarkasteltaviksi.

Omaisuusrikosten kuulustelukertomusaineistona ovat pääasiassa ns. massarikokset: näpistykset, varkaudet, petokset, kavallukset ja vahingonteot. Näiden mainittujen ns. massarikosten kuulustelukertomuksia ei tavallisesti nauhoiteta, joten tutkimusaineistooni ei sisälly nauhoitteita. Viittaan tekstiaineistoon mainitsemalla paikkakunnan (Hki, Tre, Tku), kuulustelukertomuksen (kk) numeron kyseisen paikkakunnan teksteissä, mahdollisesti samaan rikostapaukseen liittyvälle eri kuulustelukertomukselle antamani pikkuaakkosen sekä tekstin sivunumeron.

Artikkelin teoreettis-metodologiset ratkaisut nousevat empiirisestä tekstilajitutkimuksesta, jossa etsitään tekstilajille eli genrelle, tässä kuulustelukertomukselle, ominaisia piirteitä lajia edustavista teksteistä (mm. Kankaanpää 2012, 284). Tekstilajit voidaan määritellä sosiaalisesti hyväksytyiksi ja tunnistettaviksi kielellisen toiminnan tavoiksi (Fairclough 1992b, 126; Heikkinen \& Voutilainen 2012, 17-47). Mäntysen $(2003,16)$ mukaan tekstilajia muovaavat tekstiä ympäröivä konteksti, tekstilajille ominaiset rakenteet ja kielelliset piirteet. Lähestyn kontekstia ilmiönä, joka on kulttuurinen ja sosiaalinen, tilanteinen sekä intertekstuaalinen. Kulttuurinen ja sosiaalinen konteksti merkitsee artikkelissani yhteiskunnallista ja institutionaalista yhteisöä, jossa tekstejä tuotetaan ja käytetään (Mäntynen 2003, 29). Tilanteinen konteksti muodostuu vuorovaikutuksen osapuolilla ole- 
vista rooleista sekä puheenaiheesta ja kielellisestä muodosta. Intertekstuaalinen konteksti luonnehtii tekstien suhdetta aiempiin ja nykyisiinkin muihin teksteihin. (Mäntynen 2003, 29.) Intertekstuaalinen konteksti luonnehtii kuulustelukertomuksen suhdetta myös tulevaan syytteeseen tai syyttämättäjättämispäätökseen.

Artikkelin teoreettis-metodologiset valinnat kytkeytyvät lisäksi diskurssintutkimukseen. Diskurssilla tarkoitetaan tässä tutkimuksessa melko vakiintunutta kielenkäyttöä jollakin tietyllä alalla ja tietyssä kontekstissa (Pietikäinen \& Mäntynen 2009, 25). Diskurssit muodostuvat käytänteistä. Käytänteet luovat sellaisia objekteja ja merkkejä, joista diskursseissa puhutaan. (Foucault 1972, 42; Luukka 1995, 46.) Diskurssit muovaavat esimerkiksi käsitystä syyllisyydestä tai syyttömyydestä määrittelemällä, millainen toiminta voi viitata syyllisyyteen, ja rakentamalla syyllisyyttä esimerkiksi kuulustelukertomuksen kaltaiseen tekstiin. Diskurssintutkimuksessa selvitetään, kuinka erilaisia merkityksiä rakennetaan sosiaalisen ja kielellisen toiminnan avulla (Pietikäinen \& Mäntynen 2009, 140). Artikkelissani diskurssintutkimuksella tavoitellaan tietoa siitä, miten kieltä käytetään - laajasti ilmaistuna - rikosepäilyn selvittämiseen ja miten syyllisyys tai syyttömyys kirjoittuu kuulustelukertomukseen.

Analysoin kuulustelukertomuksia laadullisen lingvistisen ja tarkan tekstianalyysin avulla. Analyysi perustuu Faircloughin (1989; 1992a) sekä Hallidayn (1978) näkemyksiin kielestä ja kielenkäytöstä. Faircloughin (1989, 23; 1992a) näkemyksessä kieli on luonteeltaan konstruoivaa, ja kielenkäyttöä ohjaavat erilaiset kielelliset käytänteet, jotka syntyvät sosiaalisissa instituutioissa ja struktuureissa. Hänen (em.) kriittisen kielentutkimuksen lähestymistapansa päämääränä on kielen ja vallan yhteyksien paljastaminen. Faircloughin ajattelu pohjautuu Hallidayn (1978, 13-16) kielikäsitykseen eli ajatukseen kielen funktionaalisuudesta: sillä tehdään tekoja.

\section{MITEN SYYTÖS JA SYYLLISYYS TAI SYYTTÖMYYS KIRJOITTUU KUULUSTELUKERTOMUKSEEN?}

Syyllisyys tai syyttömyys ja syytös niiden osana voi kirjoittua kuulustelukertomukseen erilaisten diskursiivisten käytänteiden avulla.
Diskursiiviset käytänteet ovat diskursiivisen eli vuorovaikutuksellisen toiminnan tapoja, joita kulttuurinen ympäristö muokkaa. Diskursiiviset käytänteet muokkaavat kielellistä toimintaa ja helpottavat kielellisen toiminnan tunnistamista ja tulkitsemista. Toisaalta kieli muokkaa tai uusintaa diskursiivisia käytänteitä. Lisäksi diskursiiviset käytänteet liittyvät laajamittaisempiin kulttuurisiin ja sosiaalisiin toimintatapoihin. (Pietikäinen \& Mäntynen 2009, 35.) Diskursiiviset käytänteet muodostavat diskurssijärjestyksen yhdessä genrejen kanssa (Fairclough 1997, 77). Diskurssit eivät järjesty niinkään kielenpiirteiden pohjalta, vaan sosiaalisin ja yhteiskunnallisin perustein (Pietikäinen \& Mäntynen 2009, 58). Siksi analysoin diskurssijärjestystä pääpiirtein kuulustelukertomuksia tuottavan poliisiyhteisön ja niitä käyttävän yhteiskunnan näkökulmasta. Perusteellinen diskurssijärjestyksen analysointi ansaitsisi oman tutkimuksensa.

Heydon $(2005,117)$ on havainnut australialaisissa kuulusteluissa ja kuulustelukertomuksissa diskursiivisina käytänteinä syytös-kielto- tai syytös-hyväksyminen -jaksoja (myöhemmin syytös-kielto/hyväksyntä-jaksoja), todisteita ja omien näkökulmien kertomista, topiikin eli puheenaiheen säätelyä sekä erilaisia muotoiluja. Tekstiaineistoni suomalaisten kuulustelukertomusten piirteisiin kuuluu osittain samoja diskursiivisia käytänteitä kuin australialaisten. Syytös-kielto/hyväksyntä-jaksot, todisteet ja omien näkökulmien kertominen, topiikin säätely sekä muotoilut liittyvät kuulustelukertomuksen ydintehtäviin: käytänteillä selvitetään rikosepäilyä ja pohjustetaan syyteharkintaa. Käsittelen artikkelissani syytös-kielto/hyväksyntä-jaksoja sekä todisteita ja omien näkökulmien kertomista, sillä ne liittyvät syyllisyyden tai syyttömyyden kirjoittumiseen läheisemmin kuin muut käytänteet.

Tarkastelen - diskursiivisten käytänteiden sisällä - lingvististä tekstianalyysiä hyödyntäen, millaisin kielellisin valinnoin syyllisyys tai syyttömyys ja syytös niiden osana kirjoittuu kuulustelukertomukseen. Jotta syyllisyyden kirjoittumisesta saataisiin kokonaiskuvaa, analysoin soveltaen kolmenlaisia metafunktioita: miten teksti toimii sisältönä (ideationaalinen metafunktio), vuorovaikutuksena (interpersoonainen metafunktio) ja kielellisenä esityksenä 
(tekstuaalinen metafunktio) (Hiidenmaa 2000, 173-176). Selkeyden vuoksi käytän metafunktion sijaan sisällön, vuorovaikutuksen ja kielellisen esityksen käsitteitä. Ensimmäiseksi tarkastelen, millaisia tarkoitteita, toimintoja, toimijoita ja suhteita tekstissä luodaan (sisältö). Toiseksi tutkin, millainen todellisuus tekstiin rakentuu, millaisia rooleja, identiteettejä sekä osapuolten välisiä suhteita tekstissä rakentuu (vuorovaikutus). Kiinnostavia ovat esimerkiksi modaalisuus ja eräiden adverbien käyttö. Kolmanneksi selvitän, millaista kieltä teksti on ja millaisissa tehtävissä eri ilmaukset ovat (kielellinen esitys). Sisällön, vuorovaikutuksen ja kielellisen esityksen ilmenemistä on tarkoituksenmukaista analysoida soveltaen, sillä merkitykset ovat toisiinsa kietoutuneita (Halliday 1985, 23; Tiililä 2007, 23). Lisäksi kaikilla kielen ilmauksilla on samanaikaisesti oma tehtävänsä metafunktioiden ilmaisemisessa (mm. Hiidenmaa 2000, 177). (Metafunktioiden soveltamisesta esim. Hiidenmaa 2000, 173-176; Shore 2012, 163, 174-175, 177-181.)

Syyllisyyden kirjoittumiseen yhdistyy rikoksen edellytyksiin kuuluva tunnusmerkistön mukaisuus (rikoksen määritelmästä mm. Honkasalo 1965, 18; Nuutila 1997, 1). Rikoksen tunnusmerkistön problematiikkaa ovat käsitelleet mm. Honkasalo $(1965,18-20)$ sekä Nuutila (1997, 79-81). Jaottelun ongelmallisuudesta huolimatta rikoksen rakennetta on jaoteltu perinteisesti objektiiviseen ja subjektiiviseen tunnusmerkistöön (Honkasalo 1965, 20; Nuutila 1997, 80; Nuutila 2016). Rikoksen objektiiviseen tunnusmerkistöön sisällytetään teko, syy-yhteys, erityiset tunnusmerkistötekijät, tahallisuus ja tuottamus sekä oikeuttamisperusteet. Subjektiiviseen tunnusmerkistöön sisältyy se, voitiinko tekijältä edellyttää kohtuudella toisenlaista suhtautumista tekotilanteessa, voitiinko häntä moittia. Jako rikoksen objektiiviseen ja subjektiiviseen tunnusmerkistöön pohjautuu erilaiseen arvosteluperustaan. Objektiivisen tunnusmerkistön mukaisuuden perustana on teon vahingollisuus. Subjektiivisen tunnusmerkistön mukaisuuden perustana on teon moitittavuus. (Emt.)

Seuraavaksi on koottu sellaisia diskursiivisia käytänteitä ja kielellisiä ilmiöitä analyyseineen, jotka pääpiirtein kirjoittavat syyllisyyttä 168 rikoksesta epäillyn kuulustelukertomukseen.
Tekstiin kirjoittuu nimenomaan syyllisyys, kuten analyysissä osoitan.

Syytöstä ja syyllisyyttä kirjoittavat diskursiiviset käytänteet ja kielelliset valinnat muodostavat yhdeksän eritasoista kategoriaa, joiden luonnetta käsitellään kategorioiden yhteydessä:

I orientaatio- ja tekstin jäsentymistason kategoriat, jotka tekevät mahdolliseksi syyllisyyden kirjoittumisen

1) kertomuksen orientaatio ja lukijan orientaatio "syyllisyysluentaan"

2) osoitukset kuulustelustrategiasta sekä kuulustelijan ja kuulusteltavan institutionaaliset roolit

II varsinaiset syyllisyyttä kirjoittavat kategoriat

3) syytös-kielto/hyväksyntä-jaksot

4) todisteet ja omien näkökulmien esittäminen osana syytöksen muotoilemista

5) viittaukset tarkoitukselliseen toimintaan ja viittaukset syyllisyyden asteeseen

6) viittaukset yksityiskohtiin

7) viittaukset toimijuuteen

III toissijaiset, hallinnolliset kategoriat

8) lakiin perustuvat ilmoitukset

9) viittaukset rikosilmoitukseen ja muut merkinnät.

\section{Kertomuksen orientaatio ja lukijan orientaatio "syyllisyysluentaan"}

Diskursiivisten käytänteiden analyysin perusteella syyllisyys voi kirjoittua kuulustelukertomukseen eksplisiittisesti tai implisiittisesti, vihjeenomaisesti. Kuulustelukertomuksen alku voi antaa viitteitä siitä, millaisia tapahtumia kertomus mahdollisesti käsittelee (esimerkki 2):

Vajaa viikko sitten 14-vuotias C. A. tuli majailemaan luokseni. Tiesin, että hän on karannut sijoituspaikastaan Tarvasjoelta. Kämppä, jossa nyt majoitun, on kaveri[ni] hallinnassa. Tämä kaveri on nyt istumassa kahden vuoden kakkua Turun vankilassa. (Tku, kk 34, s. 2.)

Esimerkin 2 arkikielinen majailla-verbi viittaa tilapäiseen asumiseen tai oleskeluun jossakin (Kielitoimiston sanakirja 2018). Kuulusteltavan kirjoitetaan toteavan yleiskielisesti, että C. A. on karannut eli poistunut luvatta sijoituspaikastaan. Sisällön näkökulmasta käytössä on arki- ja yleiskielisiä sananvalintoja. Alun tiedoista 
muotoutuu luvattoman toiminnan merkitysvivahde, mikä antaa oman sävynsä myös sille, mitä kuulusteltava kertoo toiminnastaan. Verbi istua viittaa vapausrangaistuksen kärsimiseen ja slangi-ilmaus $k a k k u$ (vankeus)rangaistukseen (Kielitoimiston sanakirja 2018). Kuulusteltavan kaverin ilmaistaan olevan vankilassa, eikä esimerkiksi viitata siihen, ettei kaveri nyt asu mainitussa asunnossa. Nämä sisältöön liittyvät valinnat voivat orientoida lukijaa siihen, että teksti käsittelee mahdollisesti rikokseen ja siihen syyllistymiseen liittyviä tapahtumia. Cotterill (2003, $63,76)$ luonnehtii tällaista "orientoivan tiekartan" konstruoimiseksi kielellä. "Orientoivaa tiekarttaa" käytetään tekstiä luettaessa todisteiden arvioimiseen tietyllä tavalla (Cotterill 2003, 63, 76). Aineistoanalyysin perusteella suomalaisissa kuulustelukertomuksissa "orientoivan tiekartan" (emt.) avulla lukijaa voitaisiin orientoida ns. syyllisyysluentaan (emt., 19). Silloin syyllisyys - ei syyttömyys - kirjoittuisi tekstiin asteittain. "Orientoivaa tiekarttaa" tavataan noin kolmasosassa aineistoni tekstejä, joten se on verrattain yleinen piirre.

Ajallisesti järjestyneet esimerkin 2 lauseet - vajaa viikko sitten, - - on karannut - -, - - nyt majoitun - -, - - on nyt istumassa kahden vuoden kakkua - - kirjoittavat syyllisyyttä sisällön näkökulmasta. Lisäksi esimerkissä 2 on lauseita ketjuttava relatiivilause: Kämppä, jossa nyt majoitun - -.

Diskurssijärjestyksen näkökulmasta kuulustelukertomus ei aina vaikuttaisi olevan neutraali, rikosepäilyä selvittävä teksti, koska lukijaa orientoidaan lukemaan tekstistä syyllisyyteen liittyviä seikkoja. Piirre viittaa vallitsevan järjestyksen haastamiseen, sillä ohjeiden (mm. Käsikirja esitutkintapöytäkirjan laadinnasta 2007) mukaan kuulustelukertomuksella vasta selvitetään rikosepäilyä.

\section{Osoitukset kuulustelustrategiasta sekä kuulustelijan ja kuulusteltavan institutionaaliset roolit}

Kuulustelukertomuksessa näkyvät kuulustelustrategian perusteella tehdyt ratkaisut, vapaan kerronnan käyttö, kysymys-vastaus-menetelmän käyttö tai näiden yhdistelmä. Kuulustelustrategiat voi lukea diskursiivisiin käytäntei- siin. Strategia vaikuttaa siihen, miten syyllisyys voi tulla representoiduksi tekstissä. Esimerkin 3 kuulustelukertomus on vapaata kerrontaa:

- - olen ollut varkaissa N. A: $n$ kanssa Turtolan tai Muotialan alueella. Tämä tapahtui noin viikkoa tai kahta, ennen kuin murtauduimme Tampereen ammatillisen kurssikeskuksen rakennustyömaalle. (Tre, kk 24i), s. 7.)

Esimerkissä 3 on syyllisyyttä kirjoittavia yleiskielisiä ilmauksia: on ollut varkaissa ja murtauduimme Tampereen ammattikorkeakoulun rakennustyömaalle. Lisäksi kerronnassa on kielellisen esityksen ajallista järjestäytyneisyyttä: Tämä tapahtui noin viikkoa tai kahta ennen kuin murtauduimme - -.

Vapaaseen kerrontaan voidaan upottaa kysymys-vastaus-pari (esimerkki 4):

Kysyttäessä vastaan, että en tiedä T:n sukunimeä, mutta hän liikkuu asematunnelin alueella (Hki, kk 24, s. 2).

Kysymys-vastaus-parin ilmaisutapa kun-sivulausetta korvaava lauseenvastike kysyttäessä vastaan on yksi diskursiivinen käytänne. Kuulustelukertomuksessa tulee ilmaista tiedon saantitapa, esimerkiksi esitetty kysymys (Käsikirja esitutkintapöytäkirjan laadinnasta 2007, 14). Esimerkin 4 tavoin tekstistä ei aina käy ilmi esitetty kysymys. Tekstistä voi päätellä kuulusteltavalta kysytyn, tietääkö hän T:n sukunimeä. Diskurssijärjestyksen kannalta piirre viestii järjestyksen haastamisesta, koska tiedonsaantitapaa ei ilmaista ohjeiden ja totunnaisen järjestyksen mukaisesti.

Valtaosassa kuulustelukertomuksia erottuvat vuorovaikutuksen näkökulmasta viranomaisen ja kansalaiset roolit ja niiden suhde toisiinsa (esimerkki 5):

Kysymys: Käytössäsi on ollut Nokian N91mallinen matkapuhelin. Mistä se on haltuusi päätynyt?

Vastaus: Olen ostanut sen jostain. En muista milloin olen sen ostanut tai keneltä olen sen ostanut. En myöskään muista millä hinnalla ostin sen. 
K: Kyseinen puhelin on anastettu. Oletko ollut tietoinen tästä tai epäillyt asiaa?

$V$ : En ole ollut tietoinen, että puhelin on ollut anastettu.

(Tre, kk 4 b), s. 3.)

Kuulustelukertomuksessa poliisi kysyy kuulusteltavalta kansalaiselta kysymyksiä, joihin kuulusteltava vastaa. Tämä synnyttää institutionaalisen vuorovaikutusasetelman, jossa viranomainen kysyy ja kansalainen vastaa. Kuulusteltava voi myös kieltäytyä vastaamasta kysymyksiin, toisin kuin esimerkin 5 kuulustelukertomuksessa. Kysymyksen esittäjäksi representoidaan vain viranomainen, joten hänen rooliinsa kuuluu kuulustelutilanteen muodollinen johto. Vaikka kuulusteltava olisikin voinut esittää kysymyksiä, tätä ei representoida tekstissä. Kysymysten laatu on oleellinen kuulustelustrategian sekä rikosepäilyn selvittämisen kannalta (Holt \& Johnson 2010, 21-27; Karstinen 1998, 122-128; VISK \$ 1679).

Esimerkissä 5 syyllisyys kirjoittuu sisällön näkökulmasta lakikielen ilmauksin:

on kerrottu oikeuteni, on haltuusi päätynyt, on anastettu.

Syyllisyys kirjoittuu vuorovaikutuksen kannalta yleensä siten, että kuulusteltavan kansalaisen näkökulma kerrottuun korostuu. Kuulusteltava on aktiivinen toimija tai kokija (Helenius 2016, 245). Tämä ilmenee kielellisesti yksikön 1., yksikön 3. ja monikon 1. persoonan käyttönä sekä kuulusteltavan käyttäminä ilmauksina. Kuulusteltavan aktiivinen toimijuus on tekstiaineistoni suomalaisissa sekä aiemmin tutkituissa englantilaisissa ja walesilaisissa kuulustelukertomuksissa kuitenkin kuulustelijan säätelemää (Helenius 2016, 245; Haworth 2015, 196), tulosta kuulustelijan valitsemasta representaatiotavasta sekä kirjattavasta aineksesta (Helenius 2016, 234).

Vuorovaikutuksen kannalta etenkin rikoksesta epäillyn näkökulmaa tuodaan esille hänen käyttämillään ilmauksilla kohdissa, joissa esitetään rikoksen tunnusmerkistöä ja näyttöä mahdollisesta syyllisyydestä tai syyttömyydestä (Helenius 2014, 238; 241-242). Tämä näkyy esimerkissä 6:
- - minulle ilmoitettiin, että saan 500 euroa jos keikkaan mönkijän. En suostu kertomaan kuka tätä minulta kysyi.

Suunnitelma oli tehty jo valmiiksi, eli minä menisin johonkin liikkeeseen ja ottaisin mönkijä[n] koeajoon. Ainoa toive siitä millainen mönkijän pitäisi olla oli se, että se olisi nelivetoinen.

Minuun otettiin yhteyttä sen takia, että minulla on pokkaa vetää kyseinen kuvio läpi. (Tre, kk 5d), s. 3.)

Diskurssijärjestyksen näkökulmasta kuulusteltavan äänen representaatioksi usein mielletty (esim. Vesterbacka 2007) kuulustelukertomus ei ole kuulusteltavan ääntä vapaasti ja neutraalisti, vaan kuulustelijan säätelemänä ja syyllisyysluentaa tukevasti. Kuulustelukertomus siis haastaa vallitsevaa diskurssijärjestystä.

Esimerkissä 6 ajallista järjestäytyneisyyttä tuotetaan ilmauksella viime perjantaina.

Sisällön näkökulmasta ajallinen järjestäytyneisyys on merkityksellistä sen kannalta, miten suorasti, epäsuorasti, asteittain jne. syyllisyys voi kirjoittua tekstiin.

Kuulusteltava käyttää puhekielistä verbiä keikata sekä ilmausta on pokkaa vetää kyseinen kuvio läpi. Sisällön näkökulmasta kuulusteltava asetetaan omia, mahdollisesti puhekielisiä ilmauksiaan käyttämällä ottamaan (osa)vastuuta teoista ja syyllisyydestä. Myös syyllisyyden jatkumoluonne tulee esiin: kuulusteltava asemoi itsensä muiden tekemän suunnitelman toteuttajaksi, jolla on vähemmän kontrollia tapahtumaan kuin sen suunnittelijoilla. Kuulusteltava tekee itsestään vähemmän syyllisen kielellisesti konditionaalien käytöllä: menisin, ottaisin. Syyllisyyden jatkumoluonne liittyy agentiivisuuden asteeseen, jota kuulusteltava pyrkii vähentämään. Agentiivisuus on subjektin ominaisuus, joten subjekti kontrolloi meneillään olevaa tapahtumaa, on toiminnallinen ja intentionaalinen. (VISK, määritelmät $>$ A.)

Esimerkissä 6 on lisäksi argumentoivuutta: Minuun otettiin yhteyttä [mönkijän hankkimiseksi] sen takia, että - -. Diskurssijärjestyksen kannalta kuulustelukertomus näyttäytyy järjestysten välisenä kamppailuna. Kansalaisen kertoma representoituu pyrkimyksenä vähentää syyllisyyttä, mutta viranomaisen kirjaama aines 
representoituu pyrkimyksenä osoittaa tai jopa vahvistaa syyllisyyttä.

\section{Syytös-kielto/hyväksyntä-jaksot}

Syytökset ovat kuulustelijan versio tapahtumista, ja syytökset vaativat epäillyltä niitä vastaavan selonteon. Jos epäilty ei heti tai suoraan kiellä syytöstä, sitä voidaan pitää hyväksyttävänä. Selvä kielto hyväksytään ja uutta lähestymistapaa voidaan asian luonteen vaatiessa kokeilla. (Heydon 2005, 124.)

Kuulustelukertomusta voidaan ohjata kysymyksin kohti syytöstä ja ohjata kuulusteltavaa ottamaan kantaa syyllisyyteen. Tällöinkään syytöstä ei usein esitetä eksplisiittisesti. Kielellisenä esityksenä kuulustelukertomus on ikään kuin joukko syyllisyyskysymykseen liittyviä temaattisia valintoja. Poliisi voi todisteita ja omia näkökulmiaan esittämällä ohjata kertomusta kohti syytöstä ja kuulusteltavaa kohti kannanottoa syyllisyyteen. Johnsonin $(2007,111)$ mukaan kuulustelukertomuksissa juuri "kerronnallistetaan" todisteita eli sijoitetaan erilaisia faktoja osaksi kertomusta, jotta voitaisiin esittää tietynlainen versio tapahtumista. Cotterill $(2003,37)$ pohtii, kenen versio esitetään ja kenen versio on uskottava. Benneworth $(2009,560)$ puhuu "institutionaalisesti parempana pidetystä versiosta", jolle ovat tyypillisiä yksityiskohtaiset viittaukset tietynlaiseen, rikokseksi epäiltyyn toimintaan.

\section{Todisteet ja omien näkökulmien esittäminen osana syytöksen muotoilemista}

Poliisi hyödyntää muiden henkilöiden kuulustelukertomuksia todisteina ja keinona esittää toinen näkökulma kuulustellun epäillyn kertomaan tapahtumakulkuun. Tämä on analyysini perusteella yksi kielellisen esityksenkin tapa rakentaa syytöstä ja syyllisyyttä vaiheittain.

Todisteiden ja omien näkökulmien kertomista voidaan kutsua ns. kalastelukeinoksi, "fishing device" (Pomerantz 1980, 187). Keinoa hyödynnetään kuulustelussa silloin, kun poliisin ja epäillyn versiot tapahtumista poikkeavat toisistaan. Omien näkökulmien kertomisessa poliisi pyytää epäillyltä vastausta, jolloin tämä antaa mahdollisen selonteon todistetusta asiaintilasta, esimerkiksi kuvauksen asiaintilaa vastaavasta tapahtumasta. (Heydon 2005, 126.)

Esimerkki 7: KYSYMYS: Sanoitko mitään miehelle, R:lle tai J:lle ollessasi miehen luona? VASTAUS: En.

KYSYMYS: Sinun on kerrottu sanoneen että "Voisikohan tuolta saada vähän rahaa?" Pitääkö tämä paikkansa?

VASTAUS: Saatoin sanoa näin. (Tre, kk 14d), s. 3.)

Poliisin kysymyksen ilmaus on kerrottu viittaa kahden muun samaan rikostapaukseen liittyvän henkilön kuulustelukertomuksiin. Poliisi haastaa kuulusteltavan kertoman tapahtumaversion viittaamalla toisen kuulusteltavan sanomaan tietoon (Helenius 2016, 244-245). Käytänteen voi nähdä osana diskurssijärjestykseen sisältyvää kuulusteltavan kansalaisen ja viranomaisen järjestyksen välistä kamppailua. Kansalaisen representoidaan kertovan syyttömyyden mukaisen tapahtumaversionsa ja viranomaisen representoidaan ilmentävän syyllisyyttä tukevaa tapahtumaversiotaan.

Epäillyltä yleensä kysytään tapahtumakulun kirjaamisen jälkeen hänen kantaansa syyllisyyteen, ja tämä kirjataan kuulustelukertomuksen loppuun (Käsikirja esitutkintapöytäkirjan laadinnasta 2007, 19). Kannanotto syyllisyyteen voidaan katsoa myös osaksi kuulustelukertomukseen sisältyvää selontekoa rikostapauksesta (Helenius 2014, 31). Esimerkissä 8 kuulusteltavan esitetään myöntävän syyllisyytensä eksplisiittisesti myöntää-verbin aktiivimuodolla sekä rikosnimikkeenä toimivalla ryöstö-substantiivilla (rikoslaki 769/1990), 1. §):

Myönnän syyllistyneeni ryöstöön, joskaan mitään tällaista en alkujaan suunnitellut (Tre, kk 13b), s. 1).

Kuulusteltavan kannanotto syyllisyyteen tapahtumakulun jälkeen voidaan esittää seuraavasti (esimerkki 9):

- - Olin kaverini M. K:n kanssa kaupungilla. Tulimme Pub-Daily Newsista josta lähdimme kävelemään Käsityöläiskatua - -.

Huomasimme maassa markiisin joka mielestämme näytti veneeltä. Lähdimme kanta- 
maan [sitä] laulaen samalla merimieslauluja, joka meistä oli siinä mielentilassa mahdottoman hauskaa.

Seuraavaksi muistamani asia on kun poliisi otti meitä olkapäästä kiinni ja toi poliisilaitokselle asian selvittämiseksi.

Kiistän ehdottomasti, että olisimme repineet markiisin irti seinästä tai edes aiheuttaneet sille minkäänlaista vahinkoa. (Tku, kk 19, s. 2.)

Esimerkissä 9 lauseita ketjuttavilla relatiivilauseilla on merkitystä syyllisyyden kirjoittumisessa sisällön näkökulmasta: markiisin, joka mielestämme näytti - -, laulaen samalla merimieslauluja, joka meistä --.

Näkyvissä on myös se joissakin syytös-kielto/hyväksyntä-jaksoissa tavattava piirre, ettei syytöstä aina esitetä eksplisiittisesti. Syytös sisältyy kieltoon. Sisällön näkökulmasta kielto ilmaistaan kieltoverbin sijaan yksikön 1. persoonan verbimuodolla kiistää. Oletettujen väitteiden olemassaolo voidaan olettaa kielloissa siten, että väitteet kielletään, mikä tekee väitteet näkyviksi (Pietikäinen \& Mäntynen 2009, 126). Kuulusteltavan vastaus Kiistän ehdottomasti, että olisimme repineet markiisin irti seinästä - - tekee näkyväksi väitteen 'Olette repineet markiisin irti seinästä. Lisäksi esimerkissä nähdään syyllisyyden jatkumoluonne, koska epäilty kiistää syyllisyytensä ehdottomasti: hän 'ei ole lainkaan syyllinen'. Tapahtuma representoidaan ikään kuin kuvauksena lievemmästä syyllisyydestä: 'kannoimme markiisia ja lauloimme merimieslauluja'. Epäilty ei kuitenkaan myönnä tätä lievempänä esitettyäkään syyllisyyttä. Diskurssijärjestyksen kannalta kansalaisen representoidaan pitäytyvän omassa syyttömyysjärjestystä ilmentävässä tapahtumaversiossaan.

Syytöksiin vastaamisessa on lisäksi muotoja, joissa sisällön kannalta epäilty saattaa myöntää syyllisyytensä lievempään rikosnimikkeeseen, mutta kiistää syyllisyytensä vakavampaan rikosnimikkeeseen (Helenius 2014, 34) ns. rikosnimikkeen kaupankäynnillä (esimerkki 10):

Myönnän syyllistyyneni [syyllistyneeni] maksuvälinepetokseen. Kiistän syyllistyneeni varkauteen. (Tku, kk 24, s. 3.)
Carter $(2011,118)$ näkee kaupankäynnin rikosnimikkeellä muistuttavan osittaista tunnustusta (Shuy 1998). Siinä kuulusteltava lieventää omaa osuuttaan epäillyssä rikoksessa myöntämällä syyllisyytensä lievempään rikosnimikkeeseen (Carter 2011, 118; Benneworth 2010, 148). Diskurssijärjestyksen näkökulmasta kuulusteltavan voidaan katsoa pyrkivän uusintamaan syyttömyysjärjestystään myös syyllisyyttä lieventämällä.

Syytöksiä sekä kieltoja (kiistoja) ja hyväksyntöjä (tunnustuksia) kielennetään kuulustelukertomuksessa eri tavoin, mikä kuvaa sisältöön liittyvien valintojen moninaisuutta. Syytös voidaan esittää eksplisiittisesti tai syytös voidaan ilmaista implisiittisesti siten, että tilannekontekstissa saatu tieto implikoi syytöksen. Esimerkki 11 havainnollistaa tilannekontekstissa saadun tiedon hyödyntämistapaa:

- - tapasin S:n jossain vaiheessa päivää muistaakseni Turun rautatieaseman vieressä olevassa puistossa. S. soitti minulle ja pyysi kanssansa ryyppäämään. Sitten ryypiskeltiin päivä ja illalla menimme taksilla Loimaalle. Meidän mukana pyöri sen päivän aikana muutamia kavereita ja kaikkia en edes muista. En muista ketkä kaverit tulivat samaan taksiin kanssamme.

S. tarjosi silloin juotavaa ja taisi maksaa taksin. Minä en käyttänyt S:n hallussa olleita kortteja. Enkä edes tiennyt, että S:lla olisi ollut varastettu pankkikortti hallussaan.

En tiedä, mistä S. oli sen kortin saanut. Kiistän varastaneeni mitään korttia tai lompakkoa. Kiistän syyllistyneeni maksuvälinepetokseen, koska en käyttänyt puheena olevaa pankkikorttia. (Tku, kk 25, s. 2).

Tilannekontekstissa saatu tieto implikoi syytöksen pankkikortin varastamisesta ja kortin käytöstä. Kuulusteltavan kiellot ovat osa syytösten 'varasti kortin tai lompakon' sekä 'käytti varastettua pankkikorttia petoksen tekemiseen' implikaatioita. Kiisto kielennetään kaavamaisesti käyttämällä kiistää-verbin yksikön 1. persoonaa ja rikosnimikettä. Kiistossa käytetään usein kieltohakuista kvanttoripronominia mitään, joka ilmaisee, että "joukko tai paljous, josta sanottu pitäisi paikkansa, on tyhjä" (VISK $₫ 757$ ). Pronomini mitään vahvistaa kuulusteltavan kiistoa (VISK $₫ 1634$; Helenius 2014, 35). 
Kiistossa nähdään myös argumentoivuutta: Kiistän syyllistyneeni maksuvälinepetokseen, kos$k a--$. Lisäksi nähtävissä on arkikielisiä, syyttömyyden kirjoittumiseen liittyviä ilmauksia, kuten pyysi ryyppäämään, ryypiskeltiin ja mukana pyöri kavereita. Näillä sisältöön liittyvillä sananvalinnoilla kuvataan rikokseksi epäiltyä tapahtumasarjaa, jonka epäilyn kuulusteltava kiistää.

Tunnustuskin voidaan esittää kaavamaisesti ja varmaksi representoituna (ks. Pölönen 2003, 343). Varmuus kuvaa kuulustelukertomuksessa ilmeneviä, vuorovaikutukseen liittyviä valintoja. Kuulusteltavan voidaan esittää ilmaisevan hyväksyntänsä eksplisiittisesti rikosnimikkeen kera (esimerkki 12):

Tunnustan syyllistyneeni moottorikulkuneuvon käyttövarkauteen sekä kulkuneuvon kuljettamiseen oikeudetta (Tre, kk 2b), s. 4).

Esimerkissä 12 kuulusteltavan esitetään mainitsevan lakikieliset rikosnimikkeet moottorikulkuneuvon käyttövarkaus (rikoslaki 614/2002, 9. a -\$) sekä kulkuneuvon kuljettaminen oikeudetta (rikoslaki 545/1999, 10. §).

Erilaiset syyllisyyden myöntämiset ovat osa kuulusteltavan diskurssijärjestystä. Vaikka suurin osa siitä on ns. syyttömyysjärjestystä, joissakin tapauksissa kuulusteltavan järjestys siirtyy syyllisyysjärjestyksen puolelle.

\section{Viittaukset tarkoitukselliseen toimintaan ja viittaukset syyllisyyden asteeseen}

Tekstiaineistossani usein toistuva diskursiivinen käytänne ovat viittaukset intentionaaliseen, tarkoitukselliseen toimintaan (esimerkki 13):

Olin tuolloin yksin kiertelemässä kyseisessä rakennuksessa tarkoituksenani löytää sieltä jotakin anastettavaa omaisuutta (Tku, kk 14, s. 2).

Toiminnasta tuotetaan rikos juuri osoittamalla toiminta tarkoitukselliseksi (Edwards 2008, 1). Tarkoituksellisuus tai tahallisuus on mainittu rikoslain (515/2003) 5. §:ssä rangaistusvastuun edellytyksenä. Esimerkissä 13 on lisäksi sisältöön liittyvä lakikielinen ilmaus anastettavaa omaisuutta.
Esimerkki 14: Olin M. H:n luona yötä, jonne tili [tuli] E. S., M. K. ja J. - - Paikalla oli M. H:n A-niminen tyttö tai ystävä yökylässä. S., K. ja J. poistuivat nopeasti asunnosta ja aamulla A. havaitsi että hänen MP3-soitin ja kamera oli anastettu. Arvasimme heti H:n kanssa, että kuka on käynyt varkaissa. (Tku, kk 29, s. 2.)

Syyllisyys kirjoittuu kuulustelukertomukseen enimmäkseen varmasti, sillä esimerkin 14 tavoin useimmista kuulustelukertomuksista puuttuvat epävarmuuden ilmaukset. Poliisin tulee keskittyä kirjaamaan rikoksen tunnusmerkistön kannalta oleellista ainesta. Kertomus voi siksi välittää joskus varman ja suunnitelmallisen kuvan rikokseksi epäillystä toiminnasta (Pölönen 2003, 343). Diskurssijärjestyksen näkökulmasta representoitu varmuus syyllisyyden kirjoittumisessa vahvistaa viranomaisen pyrkimystä toteuttaa ns. syyllisyysjärjestystä.

Kerronnassa hyödynnetään pääosin aktiivimuotoisia verbejä (olin, tili [tuli], en muista, oli, poistuivat, havaitsi, arvasimme, on käynyt). Passiivilla (oli anastettu) on lähinnä itsestään selvää läsnäolemista kuvaava, monikon 1. persoonaa puhekielisesti korvaava tai tekijyyttä epämääräistävä tehtävä (Helenius 2016, 236; 233; Tiililä 2007, 172). Tietolähde voidaan jättää implisiittiseksi käyttämällä esimerkiksi passiivia silloin, kun lähde on itsestään selvä läsnäolija prosessissa (Tiililä 2007, 172) tai kun (institutionaalinen) toiminta on oleellisempaa kuin tekijyys (Heikkinen 2000; Viinikka 2011, 69-70). Kerronnassa käytetään lisäksi vaihtelevasti kieltomuotoja (Helenius 2014, 34-38).

\section{Viittaukset yksityiskohtiin}

Yksi diskursiivinen käytänne ovat viittaukset yksityiskohtiin (esimerkki 15):

- - olin ajanut lähellä kiinnijoutumispaikkaa sijaitsevaan ojaan Honda Accord-merkkisellä autolla, jonka olin anastanut Turun keskustassa sijaitsevasta parkkihallista (Tku, kk 23a), s. 2).

Leksikaaliset osat käsittävä adpositiorakenne lähellä kiinnijoutumispaikkaa sijaitsevaan (VISK $\$ 271$ ) yksilöi tapahtumapaikan, ja paikan adverbi lähellä ilmaisee etäisyyttä sekä sijainnin suh- 
teellisuutta kiinnijoutumispaikan ja ojaanajopaikan välillä (VISK $\$ 648$ ). Substantiivi ojaan täsmentää ojaanajopaikan. Substantiivi Honda Accord yksilöi anastetun auton. Ilmaus Honda Accord -merkkisellä autolla on myös esimerkki syyllisyyttä sisällön näkökulmasta kirjoittavasta yläkäsite-alakäsite-jaottelusta, jota tässä tosin käytetään alakäsite-yläkäsite-jaotteluna.

Kuulusteltavan voidaan esittää kuvaavan yksityiskohtaisesti epäillyn rikoksen tekotavan MA-infinitiivin adessiivilla (VISK $\$$ 492) tarkennuksineen (esimerkki 16):

Euromarket on ainoa paikka, mistä on pystynyt pääsemään sukeltamalla pulloautomaatista pullohuoneeseen ja sieltä ulos parkkihalliin (Tku, kk 40. s. 2).

Yksityiskohtaisuus on "institutionaalisesti parempana pidetyn version" piirre kuulustelukertomuksessa (Benneworth 2009, 560). Voineekin ajatella, että kyky kertoa tapahtumista yksityiskohtaisesti osoittaa kuulusteltavan olleen tekopaikalla. Toiminnan kuvaaminen yksityiskohtaisesti uusintaa syyllisyyteen liittyvää diskurssijärjestystä.

Syyllisyyden tai syyttömyyden kirjoittumisessa tavataan melko runsaasti neutraaleja adjektiiveja, kuten seuraavassa esimerkissä 17 (iso, pitkä). Adjektiivein kuvaillaan rikostapauksen selvittelyssä ja syyteharkinnan pohjustamisessa keskeisiä ihmisiä, paikkoja tai esineitä. Kuvaukset auttavat selvittämään, täyttääkö kuvailtu teko rikoksen tunnusmerkistön ja onko mahdollinen rikos tekomuodoltaan esimerkiksi lievä. Adjektiivien käyttö uusintaa rikosepäilyn selvittämiseen liittyvää diskurssijärjestystä, jossa ns. syyllisyysjärjestys ei nouse esiin yhtä voimakkaasti kuin joissakin muissa tapauksissa.

\section{Viittaukset toimijuuteen}

Esimerkissä 17 kuulusteltavan esitetään nimeävän itsensä toiminnasta vastuulliseksi (Helenius 2014, 33):

Minä otin tästä [haukkumisesta] suuttuneena $W: n$ isosta myssystä kiinni jonka alla on pitkä rastatukka ja pidin tiukasti kiinni. - - Olen varma, että tappelin W:n kanssa---. (Hki, kk 26, s. 2.)
Rikosepäilyn selvittämiseksi on täsmennettävä, kuka rikoksesta epäillyistä teki minkäkin teon. Kuulusteltavan vastuullisuus, toimijuus ja persoonamuotojen käyttö sekä niiden vaihtelu toimijuutta ilmentämässä osoittavat, kuka kirjoittuu syylliseksi ja miten lievästi tai vahvasti. Diskurssijärjestyksen näkökulmasta oleellista on ns. syyllisyysjärjestys.

Toimijuutta ja toimintaa voidaan myös yrittää luonnollistaa (esimerkki 18):

Illalla minulle tuli kuitenkin viinahimo ja hakusin (halusin) saada lisää kaljaa joten menin läheiseen valintataloon - -. Kävelin valintatalossa kaljahyllyille, josta otin mukaani pari 8 pack tölkkejä joita lähdin kantamaan käsissäni tarkoituksena anastaa ne maksamatta kun ei minulla ollut rahaa.

Muistan, että minulla tuli kassoilla jotain känää jonkun kanssa. Muistan huitoneeni käsilläni jotakin ihmistä mutta en muista ketä. Tämän on kuitenkin täytynyt olla joko myyjä tai kassalla oleva asiakas - - .

Olen huitonut kyseistä ihmistä sen takia, että olen ollut niin pahalla päällä sekä humalassa ja sen takia halusin saada kaljat mukaani. (Tre, kk 22a), s. 2.)

Kuulusteltava pyrkii oikeuttamaan syyllisyyttään luonnollistamalla toimijuuttaan ja toimintaansa (Benneworth 2010); hän esittää tapahtuneen sellaisena, jota ei ehkä olisi edes tapahtunut ilman hänen alkoholinhimoaan, huonotuulisuuttaan ja humalaisuuttaan. Esimerkissä 18 on sisältöön liittyviä arkikielisiä ilmauksia viinahimo, kaljahyllyille, känää ja pahalla päällä. Kielellisenä sisältöön liittyvänä valintana toistuvat lauseita ketjuttavat relatiivilauseet: valintataloon, joka, kaljahyllyille, josta, tölkkejä joita. Kuulusteltava lisäksi perustelee syyllisyytensä sen takia että -rakenteella.

Kuulusteltavan representoidaan liittävän syyllisyyteensä luonnollistamis- ja oikeuttamispyrkimyksiä. Ne ovat osa hänen syyttömyysjärjestyksensä ja kuulustelijan syyllisyysjärjestyksen välistä rajankäyntiä.

\section{Lakiin perustuvat ilmoitukset}

Kuulustelukertomuksiin kirjataan esitutkintalain (1987, 22.-39. §:t) mukaisia ilmoituksia 
kuulusteltavan asemasta, oikeuksista ja velvollisuuksista. Tämä vahvistaa kuulustelukertomuksen institutionaalista luonnetta ja vaikuttaa siihen, millaiseen kertomukseen lukija mahdollisesti orientoituu. Jos kuulusteltavan asemaksi on kirjattu rikoksesta epäilty, tämä voi orientoida lukijaa erilaiseen luentaan kuin jos asemaksi on kirjattu todistaja.

\section{Viittaukset rikosilmoitukseen ja muut merkinnät}

Esimerkissä 19 on virkkeen mittainen, ohjeiden (Käsikirja esitutkintapöytäkirjan laadinnasta 2007, 22) mukainen Merkitään-jakso:

Merkitään: Tampereen ammatillisen kurssikeskuksen varkaus liittyy rikosilmoitukseen 6750/R/1778/07. (Tre, kk 24i), s. 7.)

Kuulusteltavan edellisessä kappaleessa kuvaama tapahtumasarja nimetään yleiskielisesti Tampereen ammatillisen kurssikeskuksen varkaudeksi, josta lakikielisen Merkitään-maininnan mukaan on tehty lakikielisesti tunnistenumerolla ilmaistu rikosilmoitus. Mainitut valinnat liittyvät sisältöön. Viittaus rikosilmoitukseen voidaan tulkita osoitukseksi institutionaalisesta tilanteesta ja siihen liittyvistä rooleista: kansalaisen toimintaan liittyy viranomaisen tulkinnan mukaan mahdollinen rikos. Viittaus rikosilmoitukseen on kuin muistutus lukijalle siitä, että tekstissä selvitetään rikosepäilyä ja syyllisyyskysymystä.

Kuulustelukertomuksessa voi olla muitakin syyllisyyden kirjoittumiseen liittyviä merkintöjä kuin viittauksia rikosilmoitukseen. Tällaisia ovat esimerkiksi tavanomaiset merkinnät todisteiden esittämisestä (esimerkki 20):

Merkitään: Kuultavalle esitettiin kaksi mustapäistä Exec-avainta - -. (Tku, kk 22, s. 3.)

Jos rikoksesta epäilylle esitetään todisteita hänen oleskelustaan oletetulla rikospaikalla, tämän voidaan tulkita vahvistavan hänen syyllisyyttään. Lakiin perustuvat ilmoitukset, viittaukset rikosilmoitukseen sekä muut merkinnät uusintavat viranomaisen syyllisyyteen liittyvää diskurssijärjestystä.

\section{POHDINTA}

Artikkelissa tarkasteltiin, millaisin diskursiivisin käytäntein eli vuorovaikutuksellisen toiminnan tavoin syyllisyys tai syyttömyys kirjoittuu rikoksesta epäillyn kuulustelukertomukseen. Lisäksi tarkasteltiin, millaisin kielellisin valinnoin syyllisyys tai syyttömyys kirjoittuu kuulustelukertomukseen. Lähtökohtana pidettiin sitä, että kielelliset valinnat toteuttavat sisältöä, vuorovaikutusta sekä kielellistä esitystä.

Diskursiivisten käytänteiden ja kielellisten valintojen analyysi tarjoaa hallinnon tutkimuksen näkökulmasta uutta tietoa siitä, millaiset käytänteet ja valinnat ovat oleellisia, kenties jopa tyypillisiä, esitutkintaa toteuttavissa ja syyteharkintaa pohjustavissa teksteissä. Artikkeli tarjoaa myös esimerkkejä siitä, kuinka viranomaisen ja kansalaisen intressit ja diskurssijärjestykset kamppailevat tekstissä. Tämä havainnollistaa sitä, miten erilaisia tekoja viranomaistekstin sisällä tehdään. Lisäksi analyysi osoittaa, että kuulustelukertomuksessa on tendenssinä nimenomaan syyllisyyden kirjoittuminen. Samankaltaisia havaintoja on tehnyt $\mathrm{mm}$. englantilaisia kuulustelukertomuksia tutkinut Benneworth $(2009,557)$. Syyllisyyden kirjoittuminen syyteharkintaa pohjustavaan dokumenttiin on kiintoisaa, sillä kontekstina olevassa esitutkinnassa vasta selvitetään rikosepäilyä. Jääkin pohdittavaksi, onko tekstin toimivuus suomalaisessa(kin) päätöksenteossa viety ikään kuin tekstille hallinnollis-juridisesta näkökulmasta asetettua tehtävää pidemmälle, jos jo rikosepäilyä representoitaessa ja selvitettäessä kirjoitetaan syyllisyyttä.

Tekstiaineistossani on syyllisyyttä kirjoittavia diskursiivisia käytänteitä: syytös-kielto/hyväksyntä-jaksot sekä todisteet ja omien näkökulmien esittäminen. Samankaltaisia diskursiivisia käytänteitä on havaittu australialaisissa ja englantilaisissa tutkimuksissa (mm. Heydon 2005; Haworth 2015), jotka käsittelevät kuulustelua ja kuulustelukertomusta. Aineistoanalyysin perusteella vaikuttaakin siltä, että kuulustelukertomusten diskursiiviset käytänteet voisivat olla osittain universaaleja. Tämä on merkittävää, koska esitutkinta, kuulustelut ja kuulustelukertomukset ovat erilaisia eri puolilla maailmaa oikeusjärjestelmien eroavaisuuksien vuoksi.

Syyllisyyttä kirjoittavat diskursiiviset käytänteet ja kielelliset valinnat muodostavat yhdek- 
sän eritasoista ja monimuotoista kategoriaa, mikä liittyy rikostapauksesta annettujen selontekojen moninaisuuteen (Helenius 2014, 33). Syyllisyyttä kirjoittavista kategorioista muodostuu kolme pääryhmää:

I orientaatio- ja tekstitason kategoriat, joka tekevät mahdolliseksi syyllisyyden kirjoittumisen

II varsinaiset syyllisyyttä kirjoittavat kategoriat III toissijaiset, hallinnolliset kategoriat.

Syyllisyys kirjoittuu sisällön näkökulmasta ensinnäkin enimmäkseen toimintaa kuvaavilla aktiivimuotoisilla, myönteisillä tai kielteisillä verbeillä. Aktiivimuotoisilla verbeillä kuulusteltavan toiminta representoidaan siten, että hän on vastuullinen rikokseksi epäillystä toiminnasta (Helenius 2016, 238). Toiseksi syyllisyys kirjoittuu passiivimuotoisilla verbeillä, joiden käyttö on yhteydessä usein institutionalisoivan tai itsestään selvän läsnäolon luonnehtimiseen (Helenius 2016, 235-236). Verbit liittyvät kielellisenä valintana kuulustelupöytäkirja-lomakkeen otsikossa mainittuun Kuulustelukertomukseen, jossa tekstilaji nimetään kertomukseksi. Aktiivimuotoiset verbit kytkeytyvät kertomuksen kronologiaan. Kertomukseen sisältyvät tilannesidonnaiset, arvioivat ja kuvailevat selonteot: selostukset, joita kuulusteltavat esittävät rikokseksi epäillystä toiminnasta (Helenius 2014, 21). Kuvailevissa selonteoissa yksilöidään runsaasti neutraalein adjektiivein ihmisiä, paikkoja tai esineitä, jotka ovat rikosasian selvittelyssä ja syyteharkinnassa oleellisia. Kolmanneksi syyllisyys kirjoittuukin adjektiivien käytöllä. Neljänneksi syyllisyyden kirjoittumisessa hyödynnetään pääosin neutraaleja substantiiveja, mutta myös kuulusteltavan käyttämiä puhekielisiä tai muuhun tekstiin verrattuna värittyneitä, esimerkiksi lakikielisiä, ilmauksia.

Vuorovaikutukseen liittyviin valintoihin kuuluvat $\mathrm{mm}$. erilaiset modaalisuuden ilmaukset, joilla arvioidaan esim. tapahtumien todenmukaisuutta ja toteutumismahdollisuuksia (VISK määritelmät $M>$ modaalisuus). Syyllisyyden representoidaan kirjoittuvan pääosin varmasti, sillä tekstin tapaluokkana on indikatiivi, ja epävarmuuden ilmauksia on vähän. Syyllisyyden kirjoittumisessa on merkitystä myös adverbeilla eli ajan, paikan ja määrän ilmauksilla sekä teke- misen tavan kuvauksilla, jotka liittyvät erilaisiin yksityiskohtiin. Haworth $(2015,210)$ luokittelee kuvatun kaltaiset yksityiskohdat "institutionaalisesti oleellisiksi" ja Edwards $(2008,193)$ analyysiä tukeviksi. Benneworth $(2009,560)$ katsoo, että yksityiskohtaiset viittaukset toimintaan ovat osa "institutionaalisesti parempana pidettyä versiota" kuulustelukertomuksesta.

Kielellisenä esityksenä kuulustelukertomus on kuin joukko syyllisyyskysymykseen liittyviä temaattisia valintoja, kuten toimijuuteen, toiminnan tarkoituksellisuuteen ja rikosten tunnusmerkistöön liittyviä teemoja. Niitä kuljetetaan ja kehitellään tekstissä. Syyllisyys kirjoittuu kielellisenä esityksenä myös ajallisesti järjestyneillä lauseilla sekä lauseita ketjuttavilla relatiivilauseilla.

Jos aineistoanalyysiä suhteutetaan Fränden (2005, 10-11) mainitsemiin rikoksen edellytyksiin eli syyllisyyteen, tunnusmerkistön mukaisuuteen ja oikeudenvastaisuuteen, syyllisyys näyttäisi nousevan korostetusti esiin. Syyllisyys on kuulustelukertomusten kielellisissä valinnoissa enemmän esillä kuin tunnusmerkistön mukaisuus tai oikeudenvastaisuus. Ns. massarikosten kuulustelukertomuksissa sisältöön liittyvät valinnat vaikuttavat olevan tärkeimpiä syyllisyyden kirjoittumisen näkökulmasta. Vuorovaikutukseen liittyvät valinnat näyttävät olevan toiseksi tärkeimpiä ja kielelliseen esitykseen liittyvät valinnat kolmanneksi tärkeimpiä. Objektiivinen tunnusmerkistö korostuu, mm. teko, syy-yhteys, tunnusmerkistötekijät ja tahallisuus (Nuutila 2016).

Syyllisyys voi kirjoittua kuulustelukertomukseen alusta alkaen: tekstin alku voi antaa lukijalle viitteitä mahdollisesti tehtyyn rikokseen liittyvistä tapahtumista. Valtaosassa rikoksista epäiltyjen kuulustelukertomuksia syyllisyyden kirjoittuminen alkaa tekstissä vähitellen (myös Benneworth 2010, 141-151). On olemassa jatkumo erilaista, eriasteista ja vaihtelevaa syyllisyyttä (Carter 2011, 136; Helenius 2014, 33) rikostyypin, rikosnimikkeen, rikostapauksen laadun ja kuulusteltavan aseman perusteella (Helenius 2014, 42). Syyttömyys voi vaihtua syyllisyydeksi tai päinvastoin (mm. Helenius 2014, 37-38). Rikoksesta epäilty voi myöntää syyllisyytensä lievempään mutta kiistää syyllisyytensä vakavampaan rikosnimikkeeseen (ks. Carter 2011, 118; Shyu 1998). Syyllisyydestä 
voidaan myös vastuuttaa toisia henkilöitä tai syyllisyyttä voidaan rajata henkilöiden osalta eri tavoin (Helenius 2014, 33).

Viranomaisen ja kansalaisen representoidut diskurssijärjestykset ovat moninaisia. Kuulustelukertomuksessa kamppailevat kansalaisen diskurssijärjestys syyllisyyden vähentämiseksi

\section{LÄHTEET}

\section{Tekstiaineisto}

Helsinki: Talousrikoksista epäiltyjen kuulustelukertomusten 27 kopiota 2007-2008.

Tampere: Talousrikoksista epäiltyjen julkisten kuulustelukertomusten 94 kopiota 2007-2008.

Turku: Talousrikoksista epäiltyjen julkisten kuulustelukertomusten 47 kopiota 2007-2008.

\section{Lähdekirjallisuus}

Asetus esitutkinnasta ja pakkokeinoista 17.6.1988/ 575. Haettu sivulta http://www.finlex.fi/fi/laki/ ajantasa/kumotut/1988/19880575, 5.1.2017.

Benneworth, Kelly (2009). Police interviews with suspected paedophiles: a discourse analysis. SAGE Publications. Los Angeles, London, New Delhi, Singapore and Washington DC. Haettu sivulta http://journals.sagepub.com/doi/ pdf/10.1177/0957926509106410, 21.9.2017.

Benneworth, Kelly (2010). Sexual offences. Negotiating paedophilia in the investigative interview: the construction of sexual offences against children. Teoksessa Coulthard, Malcolm \& Johnson, Alison (eds.) The Routledge Handbook of Forensic Linguistis (s. 139-154). New York: Routledge.

Carter, Elizabeth (2011). Analysing Police Interviews. Laughter, Confessions and the Tape. London: Continuum International Publishing Group.

Cotterill, Janet (2003). Language and Power in Court. A Linguistic Analysis of the O. J. Simpson Trial. New York: Palgrave Macmillan.

Edwards, Derek (2008). Intentionality and mens rea in police interrogations: The production of actions as crimes. Haettu sivulta http://citeseerx.ist.psu.edu/viewdoc/download?doi=10.1.1.517.4971\&rep=rep1\&type $=$ pdf, 8.8.2017.

Ellonen, Erkki, Eija Karstinen \& Veli-Eino Nykänen (1996). Kuulustelutaktiikka. Helsinki: Sisäasianministeriö.

Elämän ja kuoleman tekstit: kirjoittaminen so- sekä viranomaisen institutionaalinen järjestys syyllisyyden osoittamiseksi ja vahvistamiseksi. Syytöksen ja syyllisyyden kirjoittuminen rikoksesta epäillyn kuulustelukertomukseen on siis hyvin moni-ilmeistä - aivan kuten rikoksetkin ovat.

siaali- ja hoitotyössä (2017). Toimittaneet Ulla Tiililä ja Kati Karvinen. Kotimaisten kielten keskuksen verkkojulkaisuja 50. Kotimaisten kielten keskus. Helsinki. Haettu sivulta http:// scripta.kotus.fi/www/verkkojulkaisut/julk50/ Elaman_ja_kuoleman_tekstit.pdf, 15.3.2018.

Esitutkintalaki 30.4.1987/449. Haettu sivulta http://www.finlex.fi/fi/laki/ajantasa/kumotut/1987/19870449, 5.1.2017.

Esitutkintalaki 22.7.2011/805. Haettu sivulta http://www.finlex.fi/fi/laki/ajanta$\mathrm{sa} / 2011 / 20110805,5.1 .2017$.

Fairclough, Norman (1992a). Critical Language Awareness. London: Longman.

Fairclough, Norman (1992b). Discourse as Social Change. Cambridge: Polity press.

Fairclough, Norman (1997). Miten media puhuu. Suom. V. Blom ja K. Hazard. Tampere: Vastapaino.

Foucault, Michel (1972). The Archaelogy of Knowledge. London: Tavistock Publications.

Frände, Dan (2005). Yleinen rikosoikeus. Suom. Markus Wahlberg. Helsinki: Edita.

Hahn, Gerald \& Günther Schicht (1992). Vernehmungsstrategie. Überlegungen zum Strategiebegriff. Kriminalistik 46 (5), 291-294.

Halliday, Michael A. K. (1978). Language as social semiotic. The social interpretation of language and meaning. London: Edward Arnold.

Haworth, Kate (2015). The discursive construction of evidence in police interviews: case study of a rape suspect. Haettu sivulta http://applij.oxfordjournals.org/content/early/2015/04/27/applin. amv009.full.pdf + html, 7.7.2016.

Holt, Elizabert \& Johson, Alison (2010). Legal talk. Sociopragmatic aspects of legal talk: police interviesws and trial discourse. Teoksessa Coulthard, Malcolm \& Johnson, Alison (eds.) The Routledge Handbook of Forensic Linguistis, (s. 21-36). New York: Routledge.

Honkasalo, Brynolf (1965). Suomen rikosoikeus. Yleiset opit. Ensimmäinen osa. Toinen painos. Helsinki: Suomalaisen lakimiesyhdistyksen julkaisuja. B-sarja. N:o 28. 
Heikkinen, Vesa \& Eero Voutilainen (2012). Genre - monitieteinen näkökulma. Teoksessa

Heikkinen, Vesa, Eero Voutilainen, Petri Lauerma, Ulla Tiililä \& Mikko Lounela (toim.) Genreanalyysi - tekstilajitutkimuksen käsikirja. Kotimaisten kielten keskuksen julkaisuja 169. Helsinki: Gaudeamus, 17-47.

Helenius, Jutta (2014). Kuulustelukertomus selonteon näkökulmasta. Suomen soveltavan kielitieteen yhdistyksen AFinLAn sähköinen julkaisu AFinLA-e 7/2014, (s. 20-45). Haettu sivulta http://ojs.tsv.fi/index.php/afinla/article/ view/48158/13959, 4.7.2016.

Helenius, Jutta (2016). Institutionaalinen moniäänisyys kuulustelukertomuksessa. Puhe ja kieli 4 / 2016, (s. 227-250). Haettu sivulta http://journal.fi/pk/article/view/60269/21155, 23.3.2017.

Heydon, Georgina (2005): The Language of Police Interviewing - A Critical Analysis. Basignstoke: Palgrave.

Hiidenmaa, Pirjo (2000). Lingvistinen tekstintutkimus. Teoksessa Sajavaara, Kari \& PiirainenMarsh, Arja (toim.) Kieli, diskurssi ja yhteisö. Soveltavan kielentutkimuksen teoriaa ja käytäntöä 2, (s. 161-190). 2., muuttamaton painos. Jyväskylän yliopisto: Soveltavan kielentutkimuksen keskus.

Johnson, Alison (2007). Police interviews - from talk to text and text to talk. Collecting

evidence: calls to the emergency services and first encounters with witnesses and suspects. Teoksessa M. Coulthard and A. Johnson (eds.) An introduction to forensic linguistics. Language in evidence, (s. 80-82). London: Routledge,

Kankaanpää, Salli (2012). Tekstilajin muutoksen laadullinen tutkiminen. Teoksessa Heikkinen, Vesa, Eero Voutilainen, Petri Lauerma, Ulla Tiililä \& Mikko Lounela (toim.) Genreanalyysi - tekstilajitutkimuksen käsikirja, (s. 284-295). Kotimaisten kielten keskuksen julkaisuja 169. Helsinki: Gaudeamus.

Karstinen, Eija (1998). Keskustelusta pöytäkirjaksi. Kuulustelijoiden ja rikoksesta epäiltyjen viestintä poliisikuulustelussa. Poliisiammattikorkeakoulun tutkimuksia 2/1998. Espoo: Poliisiammattikorkeakoulu.

Kielitoimiston sanakirja (2018). Sähköinen sanakirja. Haettu sivulta https://www.kielitoimistonsanakirja.fi/, 16.4.2018.

Korkein oikeus (2014). Oikeudenkäyntimenettelyä koskevia periaatteita > eräitä keskeisiä rikosoikeudenkäynti koskevia periaatteita > syyttömyysolettama. Haettu sivulta http://korkeinoikeus.fi/fi/index/muutoksenhakijalle/oikeudenkayntimenettelyakoskeviaperiaatteita.html, 6.9.2017.
Käsikirja esitutkintapöytäkirjan laadinnasta (2007). Helsinki: Sisäasiainministeriö.

Käsikirja esitutkintapöytäkirjan laadinnasta (2010). Poliisihallitus. Helsinki: Sisäasiainministeriö.

Laki rikoslain muuttamisesta 769/1990. Haettu sivulta http://www.finlex.fi/fi/laki/alkup/1990/ 19900769, 19.1.2017.

Laki rikoslain 28. luvun muuttamisesta 614/2002. Haettu sivulta http://www.finlex.fi/fi/laki/alkup/2002/20020614, 9.3.2017.

Luukka, Minna-Riitta (1995). Puhuttua ja kirjoitettua tiedettä. Funktionaalinen ja yhteisöllinen näkökulma tieteen kielen interpersonaalisiin piirteisiin. Jyväskylä Studies in Communication 4. Jyväskylän yliopisto.

Mäntynen, Anne (2003). Miten kielestä kerrotaan. Kielijuttujen retoriikkaa. Suomalaisen Kirjallisuuden Seuran Toimituksia 926. Helsinki: Suomalaisen Kirjallisuuden Seura.

Nuutila, Ari-Matti (1997). Rikoslain yleinen osa. Helsinki: Kauppakaari Oy. Lakimiesliiton Kustannus.

Nuutila, Ari-Matti (2016). Rikostunnusmerkistö. Tieteen termipankki. Haettu sivulta http://tieteentermipankki.fi/wiki/ Oikeustiede:rikostunnusmerkist\%C3\%B6, 26.2.2018.

Pakkokeinolaki 806/2011. Haettu sivulta http://www.finlex.fi/fi/laki/alkup/2011/20110806\#Lidp2847072, 5.1.2017.

Pietikäinen, Sari \& Mäntynen, Anne (2009.) Kurssi kohti diskurssia. Tampere: Vastapaino.

Poliisilaki 497/1995. Finlex-tietokanta. Haettu sivulta http://www.finlex.fi/fi/laki/ajantasa/1995/19950493, 23.3.2017.

Poliisilaki 872/2011. Finlex-tietokanta. Haettu sivulta http://www.finlex.fi/fi/laki/alkup/2011/20110872, 23.3.2017.

PolStat (2017). Poliisin tulostietojärjestelmästä saadut tiedot vuoden 2016 rikosmääristä. Haettu sivulta http://www.polamk.fi/instancedata/ prime_product_julkaisu/intermin/embeds/ polamkwwwstructure/64914_Polstat_tilastot_ loka2017.pdf?51cd5dfe081dd588, 12.12.2017.

Pomerantz, Anita (1980). ”Telling My Side: Limited Access" as a "Fishing" Device. Sociological Inquiry. 50(3-4), 186-198.

Pölönen, Pasi (2003). Henkilötodistelu rikosprosessissa. Helsinki: Suomalainen lakimiesyhdistys.

Rikoslaki 19.12.1889/39 ja 769/1990. Finlextietokanta. Haettu sivulta http://www.finlex. fi/fi/laki/ajantasa/1889/18890039001\#L31, 28.3.2017. 
Rikoslaki 531/2007. Finlex-tietokanta. Haettu sivulta https://www.finlex.fi/fi/laki/alkup/2007/20070531\#Pidm1930896, 3.9.2015.

Rikoslaki 614/2002. Finlex-tietokanta. Haettu sivulta http://www.finlex.fi/fi/laki/alkup/2002/20020614, 12.12.2017.

Rikoslaki 13.6.2003/515. Finlex-tietokanta. Haettu sivulta http://www.finlex.fi/fi/laki/ajantasa/1889/18890039001\#L3, 27.2.2018.

Shore, Susanna (2012). Systeemis-funktionaalinen teoria tekstien tutkimuksessa. Teoksessa Heikkinen, Vesa, Eero Voutilainen, Petri Lauerma, Ulla Tiililä \& Mikko Lounela (toim.) Genreanalyysi - tekstilajitutkimuksen käsikirja, (s. 158-185). Kotimaisten kielten keskuksen julkaisuja 169. Helsinki: Gaudeamus.

Shuy, Roger W. (1998). Language Crimes. The Use and Abuse of Laguage Evidence in the Courtroom. Oxford. Blackwell.

Solin, Anna (2012). Genremuutos ideologisena prosessina. Normiristiriidat ja uuden genren kotouttaminen. Virittäjä 3/2012, 349-377.

Tiililä, Ulla (2007). Tekstit viraston työssä. Tutkimus etuuspäätösten kielestä ja konteksteista. SKS:n toimituksia 1108. Helsinki: Suomalaisen Kirjallisuuden Seura.

Vainikkala, Erkki (2012). Kulttuurintutkimus. Teoksessa Heikkinen, Vesa, Eero Voutilainen, Petri Lauerma, Ulla Tiililä \& Mikko Lounela (toim.) Genreanalyysi - tekstilajitutkimuksen käsikirja, (s. 564-580). Kotimaisten kielten keskuksen julkaisuja 169. Helsinki: Gaudeamus. van der Sant, Rob (2010). Pragmatic Strategies. In Zimmermann, Thomas Ede, Reyle, U. Bäuerle, Rainer (authors): Presuppositions and Discourse: Essays Offered to Hans Kamp. Bingley, UK : Brill NV. 2010. Current Research in the Semantics/Pragmatics Interface, volume 21. E-kirja. Haettu sivulta http://web.b.ebscohost.com/ehost/ebookviewer/ebook/bmx1YmtfXzcwOTkyMV9fQU41? sid=fc57c3472499-411d-921d-84d46a6ae636@sessionmgr102\&vid=0\&format $=E B \& l p i d=1 p \_29 \&$ rid $=0$, 9.10.2017.

Vesterbacka, Marko (2007). Kuulustelukertomuksen kirjaamisesta. Opetusmoniste. Tampere: Poliisikoulu.

Viinikka Jenni (2011). Kuoleman kielissä. Suomen kielen pro gradu -tutkielma. Helsingin yliopisto Haettu sivulta https://helda.helsinki.fi/ bitstream/handle/10138/26517/kuoleman.pd$\mathrm{f}$ ? sequence $=1,13.1 .2016$

VISK = Hakulinen Auli, Maria Vilkuna, Riitta Korhonen, Vesa Koivisto, Tarja R. Heinonen \& Irja Alho (2004). Iso suomen kielioppi. Verkkoversio. Helsinki: SKS.

URN: ISBN:978-952-5446-35-7. Haettu sivulta http://scripta.kotus.fi/visk, 8.5.2018. 